\title{
Design and Fabrication of a Modular Melon Depodding Machine for Optimum Performance in Nigerian Agricultural Sector
}

\author{
Osasumwen Godswill Ogiemudia $\mathbb{D}^{D}$, Aniekan Essienubong Ikpe* ${ }^{*}$, Lucky Efe Chughiefe
}

University of Benin, Department of Mechanical Engineering, PMB 1154, Nigeria

\begin{abstract}
The traditional methods of depodding melon pods to extract the edible seeds is a time consuming and tedious process. A melon depodding machine was therefore designed, fabricated and tested for use in Nigeria. The fabricated machine had the following operating units: depodding chamber, power system, feeding hopper, supporting frame, electric motor, gear shaft, discharge unit etc. The average mass of melon pod of $1.671 \mathrm{~kg}$ and the average diameter of the melon pod of $139.25 \mathrm{~mm}$ were obtained experimentally. From the performance test carried out on the machine, average percentage of depodded seeds of $91.1255 \%$, average percentage of undepodded seeds of $7.2915 \%$, the average percentage of damaged seeds of $1.5835 \%$ and the average percentage of useful seeds of $98.4165 \%$. Considering the aforementioned results, the melon depodding machine designed in this study can perform optimally in both domestic and commercial level in Nigeria.
\end{abstract}

Keywords: Melon pods, Depodding machine, Design, Fabrication, Agriculture, Food.

\section{INTRODUCTION}

The main occupation of residents in rural areas in Nigeria is agriculture [1]. Processing of agricultural products into food items suitable for being consumed for a longer period without spoilage can prolong the useful life of such products and can also increase the net profit for farmers [2]. However, several tones of melon pods are gathered every harvesting period but the majority of the total harvest is processed using traditional/manual methods. Melon seed (Cucumis Melo) is a popular food source consumed mostly by Africans. It has been referred to in some texts as Citrullus Vulgaris [3] or Colocynthis Ecirrhosus [4]. In Nigeria, it goes by the following names 'egusi' (Yoruba), 'ogili' (Ibo), 'ogi' (Bini), and 'iguana agushi' (Hausa) and 'dènde' (Fulani). The shelled seeds of egusi are usually coarsely ground and used in preparing soup, stew, and snacks. It is used preparing robo, a defatted fried cake obtained after the oil has been extracted from the melon seed. The seeds can also be fermented, boiled, and wrapped in leaves to form a favourite food seasoning 'Ogiri'. Melon seed contains about 314gkg-1DM crude protein, $439.3 \mathrm{gKg}-1 \mathrm{DM}$ crude fat, 31.4-90.6 gkg-1DM crude fibre, 2.4-4.6 gkg-1DM phosphorus, 3.9-6.5 gkg-1DM potassium and 4.1-5.9 Mcalkg-1DM energy [5]. The seed also contain about $50 \%$ oil, $30 \%$ protein, $10 \%$ carbohydrate, $4 \%$ ash, $3 \%$ vitamin, and 3\% fiber [6]. The melon seed is a rich source of amino acids like arginine, methionine, and tryptophan. Me- lon seeds have found widespread use in the following areas: as a source of food, as a source of medicine in the healthcare industry, used in the skincare industries, and source of feeds for animals and as a source of income to farmers. Studies have shown that melon pods have an almost spheroidal external shape and an ellipsoidal seed cavity, sphericity of 1.03, an average density of $0.87 \mathrm{~g} / \mathrm{cm} 3$, and seed content of $3.5 \%$ by weight. $[7,8]$.

In Nigeria, due to the sociology of different ethnic groups in the country, melon seeds (egusi) are now being transported all over the country where it is served as a meal. Egusi is commonly prepared as soup with vegetables, peppers, spices, palm oil, meat, fish, and other ingredients and sometimes eaten with pastes known as swallows, for example, pounded yam, fufu, wheat, amala, eba, etc. $[9,10]$.

The oil extracted from the melon seeds can be used in the manufacture of margarine, shortening, and cooking oils, while the residual cake is a useful source of protein for livestock feed [11].

Melon seeds may account for up to $80 \%$ of dietary protein and may be the only affordable source of protein for some people $[12,13]$. The need to increase and improve melon production in the farming system, human diets, and health cannot be overemphasized [14].

Processing of melon into eatable items involves depodding,
* Corresponding authour

Email: aniekan.ikpe@eng.uniben.edu
European Mechanical Science (2020), 4(3): 103-112 doi: https://doi.org/10.26701/ems.729747

Received: April 30, 2020

Accepted: May 8, 2020 
fermentation, washing drying, cleaning, and shelling [15]. The process of breaking melon pods to remove seeds is known as melon depodding. The traditional/manual processing of melon is time-consuming, unsanitary, and laborious. These include manual depodding of melon fruit and bio-decomposition of the fruits in a heap. These techniques are not only energy-sapping and time-consuming, but they also yield low-quality products, while the rotten pods contribute to environmental pollution [16].

The mechanical method is an alternative processing option for melon seeds, as it improves the quality and quantities of the produce by eliminating pest infestation. The manual depodding process of melon has various challenges such as bio-decomposition and fermentation of melon pods and challenges in scooping and washing of the melon seeds.

Jackson et al. (2013) [17] investigated the effects of two varieties of melon pod fermentation on the proximate and mineral composition of the melon seeds. Comparing the seeds obtained from fermented pods and those from unfermented pods indicated negligible differences in the composition of the seeds. Results revealed that the moisture content for the fermented samples was between $5.3 \pm 0.1 \%$ and $5.8 \pm 0.3 \%$ while $5.3 \pm 0.1 \%$ and $5.6 \pm 0.3 \%$ were obtained from the unfermented seeds for the Bara and Sewere. The results also revealed that fermentation does not affect the mineral compositions of the melon seed and has no significant effect on the quality of the seed at the $5 \%$ significant level using the Duncan Multiple Range Test.

Using an impeller speed between 1400 and $1800 \mathrm{rpm}$ at a moisture content of $16.47 \% \pm 2$, Oriaku et al. [18] obtained a percentage breakage between 40 and $80 \%$. However, with an optimum speed of $1000 \mathrm{rpm}$, the breakage percentage reduced to $12 \%$ for the impact approach and $1 \%$ for the attrition approach. Nwakuba [19] developed a melon depodding machine with a maximum capacity of $25 \mathrm{~kg}$ of melon per batch, powered by $1.5 \mathrm{~kW}, 1140 \mathrm{rpm}$ single-phase electric motor. The performance characteristics of the machine evaluated at six operating speeds $(200,250,300,350,370$, and $400 \mathrm{rpm}$ ) were: depodding efficiency, material discharge efficiency, and overall efficiency. The Depodding efficiency varied between $32 \%$ and $74 \%$, the seed discharge efficiency varied between $22 \%$ and $70 \%$, the pulp discharge efficiency varied between $0.6 \%$ and $2.1 \%$, while the overall efficiency varied between $7.2 \%$ and $53.4 \%$. In all, the maximum efficiency occurred at the operating speed of $300 \mathrm{rpm}$. Oloko and Agbetoye [20] developed and evaluated a melon depodding machine with average depodding efficiency were observed to range from $65.6 \%$ at speed of $200 \mathrm{rpm}$ to optimum level of $82.1 \%$ at speed of $300 \mathrm{rpm}$ before reducing gradually to $31.8 \%$ at speed of $400 \mathrm{rpm}$. The overall efficiency of the depodding machine was reported to be $68.8 \%$, at an optimal speed of $300 \mathrm{rpm}$.

Scooping and washing of fermented melon during processing are one of the main reasons why post-harvesting of me- lon is considered difficult. Melon pods after fermentation cause serious environmental pollution and are exposed to various insects and flies, thereby, making the environment unconducive for human habitation. This is one major factor while melon crops are not being cultivated in gardens close to the residential apartment.

Mechanical means of depodding fresh melon pods has become a major concern in this study, as it can help eliminate the stress involved during scooping as well as washing of the melon, and can also reduce the time spent during decomposition and fermentation. Therefore, a fresh melon depodding machine was designed, fabricated, and tested in this study for an optimum performance suitable in the Nigerian agricultural sector.

\section{MATERIALS AND METHOD}

The major components of the machine are the frame, hopper, stationery knife, blades, circular plate, driving and driven shaft, speed reducer unit, electric motor, bearings, chain, and sprocket, separation chamber, switch box, pulp outlet, seeds outlet, and fasteners. Material specifications for the melon depodding machine are presented in Table 1.

Table 1. Material specifications for the melon depodding machine.

\begin{tabular}{|c|c|c|c|c|}
\hline $\mathrm{S} / \mathrm{N}$ & Component & Material & Dimensions (Mm) & Qty \\
\hline 1. & Electric motor & Copper coil & $2.5 \mathrm{HP}$ & 1 \\
\hline 2. & Gearbox & Alloy steel & Length $350 \mathrm{~mm}$ breath $298 \mathrm{~mm}$ & 1 \\
\hline 2. & Bearing & Stainless Steel & & 1 \\
\hline \multirow{4}{*}{3.} & \multirow{4}{*}{ Plate } & Stainless Steel & PL $2 \mathrm{~mm} \times 1219.2 \mathrm{~mm} \times 2438.4 \mathrm{~mm}$ & 1 \\
\hline & & Carbon steel & PL $2 \mathrm{~mm} \times 1219.2 \mathrm{~mm} \times 2438.4 \mathrm{~mm}$ & 1 \\
\hline & & Carbon steel & PL $2 \mathrm{~mm} \times 1219.2 \mathrm{~mm} \times 2438.4 \mathrm{~mm}$ & 1 \\
\hline & & Carbon steel & $\mathrm{PL} 2 \mathrm{~mm} \times 1219.2 \mathrm{~mm} \times 2438.4 \mathrm{~mm}$ & 1 \\
\hline 4. & Chain & Alloy steel & Length $450 \mathrm{~mm}$, Breath $1.5 \mathrm{~mm}$ & 1 \\
\hline 5. & Big Sprocket & Cast iron & Dia.; 100 & 1 \\
\hline 6. & Small Sprocket & Cast iron & Dia.; 50 & 1 \\
\hline 7. & Solid Shaft & $\begin{array}{c}\text { Stainless Steel } \\
\text { (ASTM A36) }\end{array}$ & $\begin{array}{c}\text { Length: } 320 \\
\text { Dia: } 35\end{array}$ & 1 \\
\hline 8. & Mild Steel Plate & $\begin{array}{c}\text { Mild Steel } \\
\text { (ASTM A36) }\end{array}$ & $\begin{array}{l}\text { Length: } 5500 \\
50 \times 50 \times 20\end{array}$ & 1 \\
\hline 9. & Circuit Breaker & Ceramic & L: 135, W: 78, H: 73.5 & 1 \\
\hline 10. & Bolt \& Nut & $\begin{array}{c}\text { Mild Steel } \\
\text { (ASTM A36) }\end{array}$ & M12 and M18 & 1 \\
\hline 11. & Electrode & Graphite & D:2.5, L: 350 , Current: $90-250 \mathrm{~A}$ & 3pck \\
\hline
\end{tabular}

For each major component used in the design of the melon depodding machine, a summary was provided to justify the material and reasons why such material is selected. Justification of materials selected for the design is presented in Table 2. Before the melon depodding machine was fabricated, SOLIDWORKS software, 2017 version was employed in representing the isometric and orthographic views of the major components, as well as the well-labeled assembly drawing represented in exploded view. SOLIDWORKS is a solid modelling Computer Aided Design (CAD) as well as Computer Aided Engineering (CAE) tool that runs mainly on Microsoft Windows. Modelling procedure of the melon depodding machine in this study started with 2D sketch, consisting of geometries such as arcs, points, conics, lines, splines and so on. Dimensions were added to the sketch to 


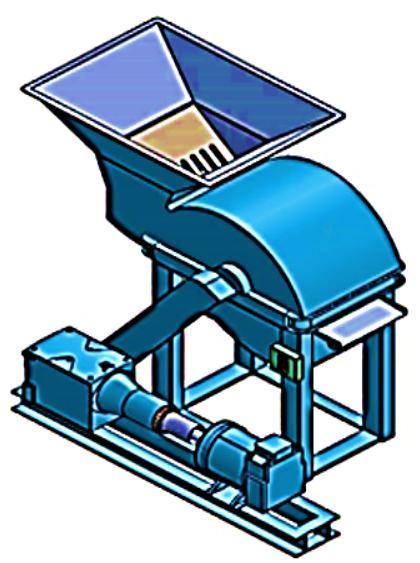

a.

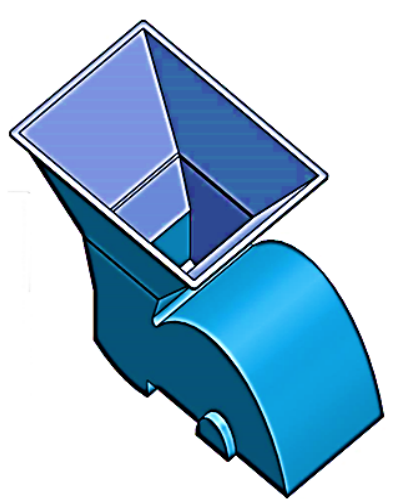

a.

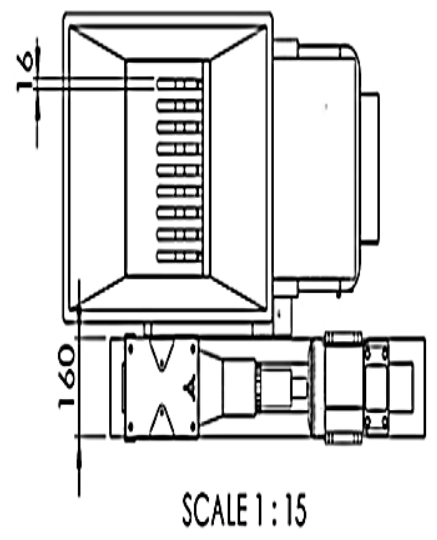

b.

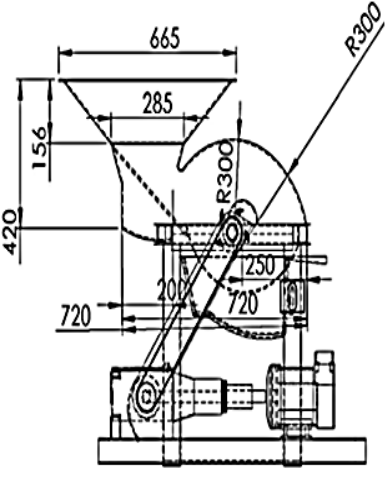

SCALE $1: 15$

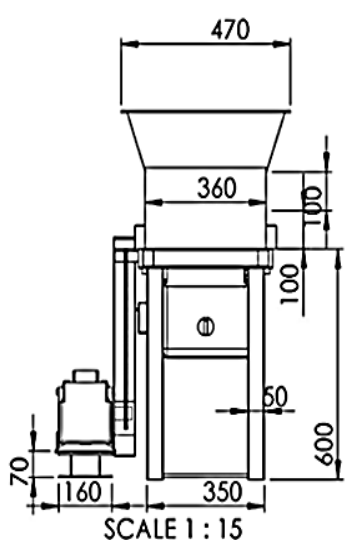

d.

Figure 1. Isometric and orthographic views of melon depodding machine

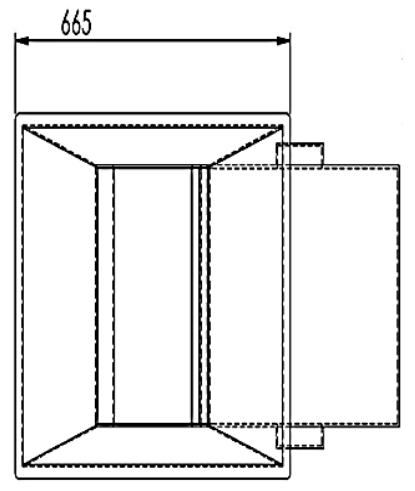

b.

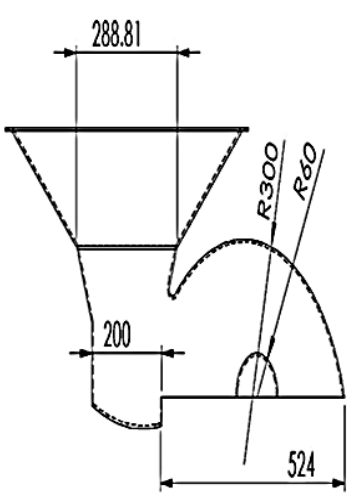

c.

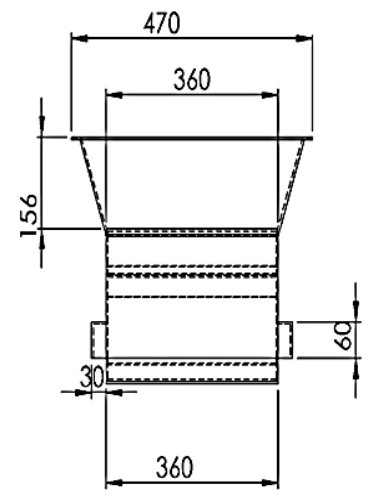

d.

Figure 2. Isometric and orthographic views of Hopper in a melon depodding machine

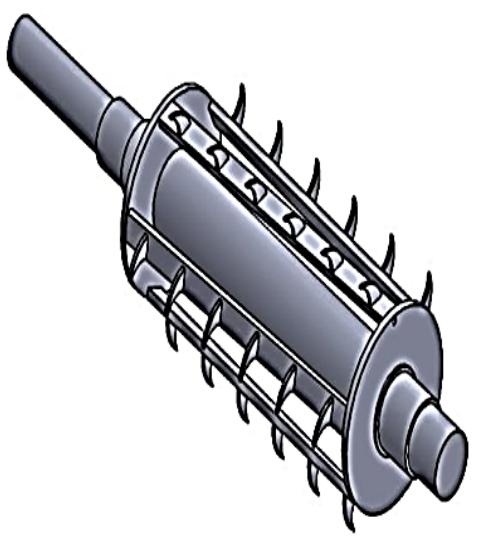

a.

a.

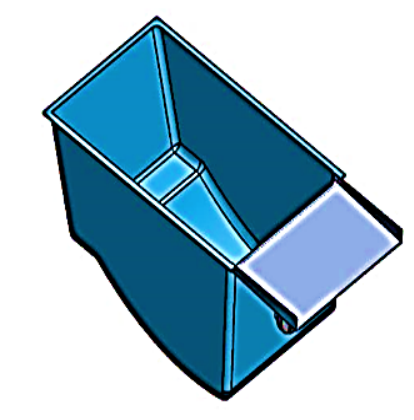

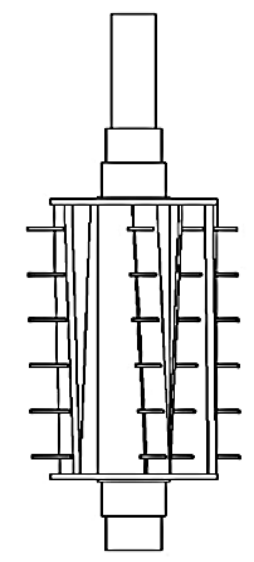

b.

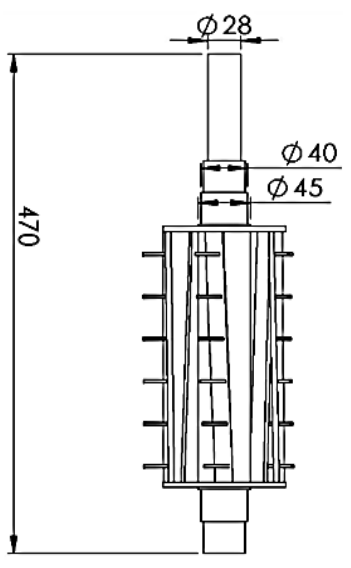

c.

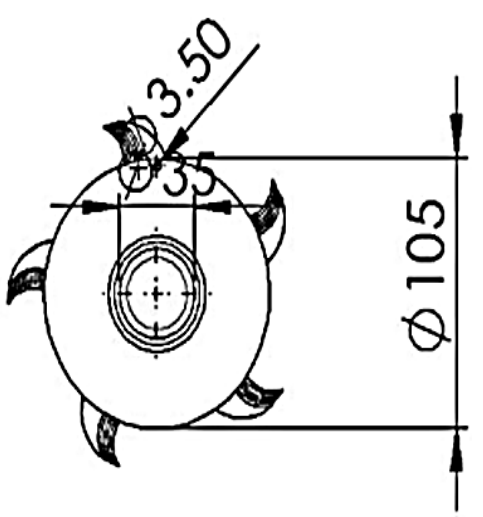

d.

Figure 3. Isometric and orthographic views of the Depodding chamber in the machine

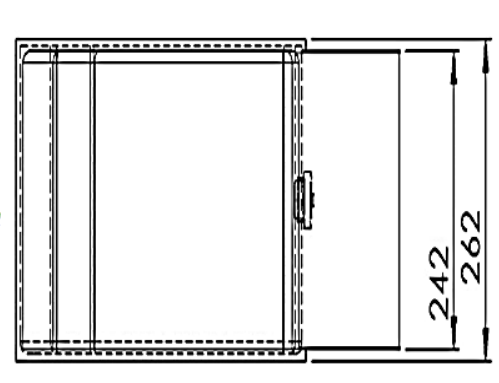

b.

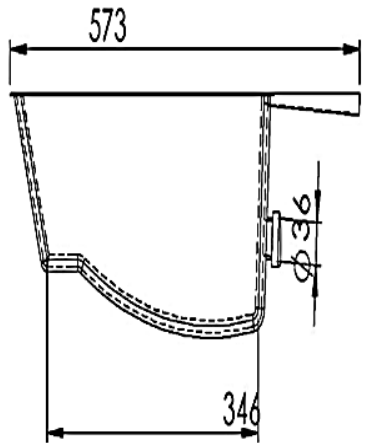

c.

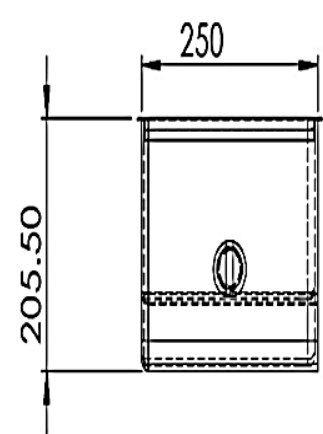

d.

Figure 4. Isometric and orthographic views of separation chamber in the machine 


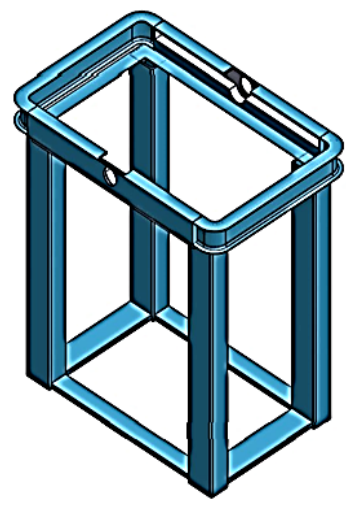

a.

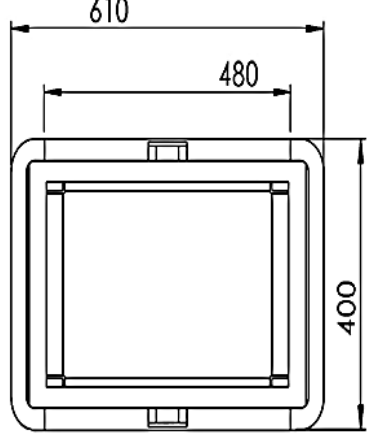

SCALE $1: 10$

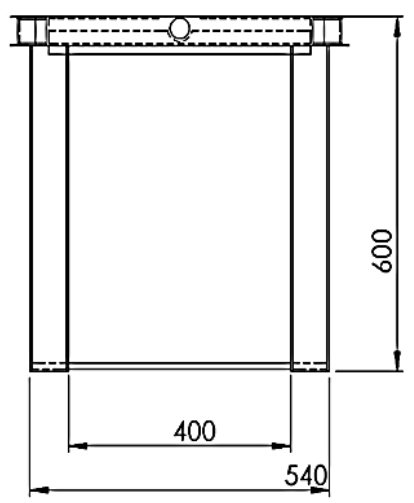

c.

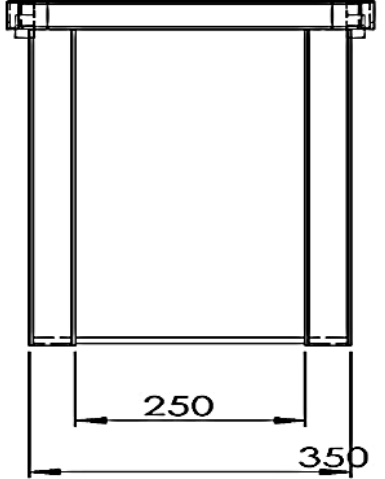

d.

Figure 5. Isometric and orthographic views of the main frame in the machine

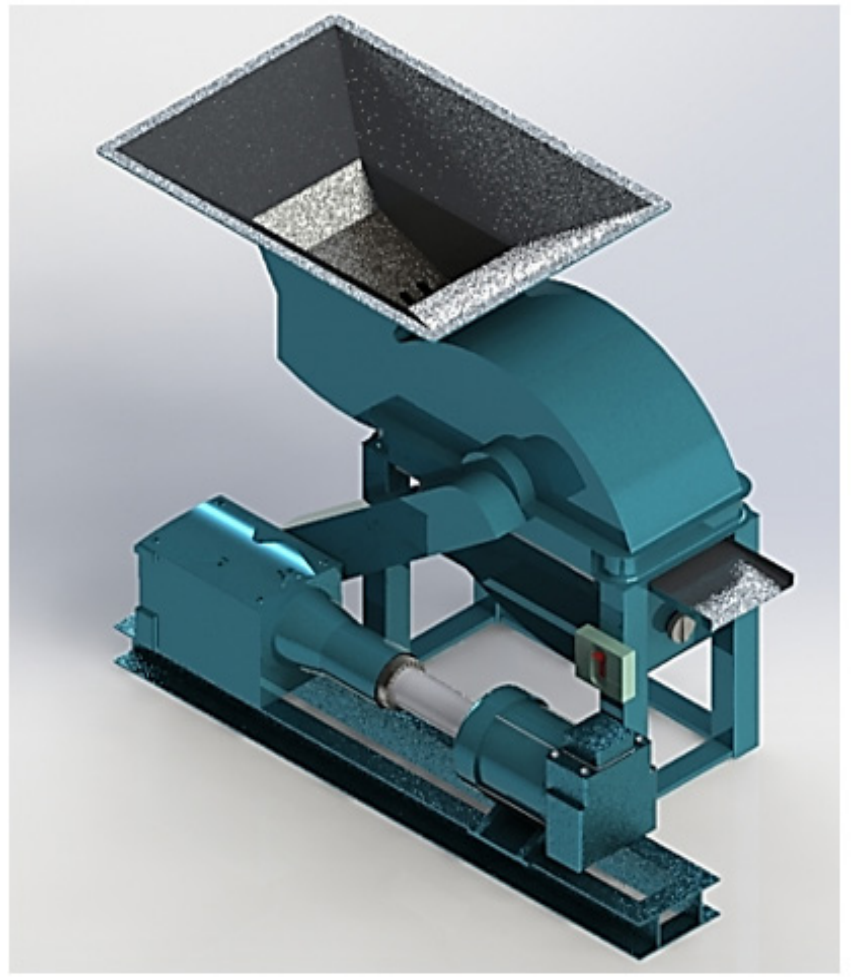

a. Isometric View of Melon Depodding Machine

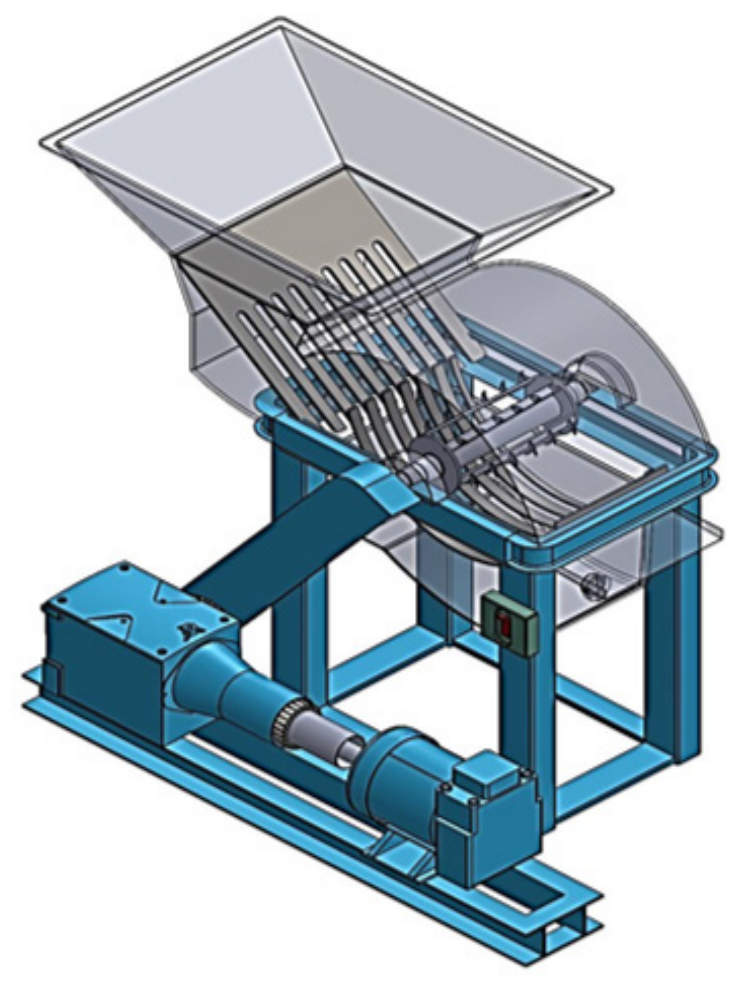

b. Skeletal View of the Machine

Figure 6. Assembly drawing of the melon depodding machine

Table 2. Justification of materials selected for the design

\begin{tabular}{|c|c|c|c|}
\hline Design Specification & Function & Material & Justification \\
\hline Shaft & Transmission of torque. & $\begin{array}{l}\text { medium carbon } \\
\text { steel }\end{array}$ & $\begin{array}{l}\text { Good corrosion resistance, ability to absorb shear } \\
\text { force and } \\
\text { Compressive force without exceeding the allowable } \\
\text { torsional shear stress. }\end{array}$ \\
\hline Sprocket & $\begin{array}{l}\text { Transmits rotary motion between a pair } \\
\text { of shafts. }\end{array}$ & Cast iron & $\begin{array}{l}\text { Ability to reduce speed from the } \\
\text { electric motor for effective operation }\end{array}$ \\
\hline Chain & $\begin{array}{l}\text { For power transmission from electric } \\
\text { motor }\end{array}$ & Alloy steel & $\begin{array}{l}\text { Low speed and high torque } \\
\text { operation }\end{array}$ \\
\hline Power & $\begin{array}{l}\text { For conversion of electricity to mechani- } \\
\text { cal power. }\end{array}$ & $\begin{array}{l}\text { Low speed } \\
\text { motor }\end{array}$ & For effective power consumption at minimal cost. \\
\hline Frame & $\begin{array}{l}\text { For support of machine parts, provides } \\
\text { rigidity for the machine. }\end{array}$ & $\begin{array}{l}\text { Mild Steel bar and } \\
\text { Angle bar }\end{array}$ & High structural strength and rigidity. \\
\hline Mechanical Bearings & $\begin{array}{l}\text { Allows rotational movement of the shaft, } \\
\text { reducing friction and enhancing perfor- } \\
\text { mance to save energy. }\end{array}$ & Alloy steel & $\begin{array}{l}\text { High strength, ability to withstand wear and fatigue } \\
\text { failure }\end{array}$ \\
\hline Blades & $\begin{array}{l}\text { Sharp and capable of depodding the } \\
\text { melon pods. }\end{array}$ & Stainless steel & $\begin{array}{l}\text { High strength and toughness, Good corrosion resis- } \\
\text { tance ability, NAPDAC specification }\end{array}$ \\
\hline
\end{tabular}




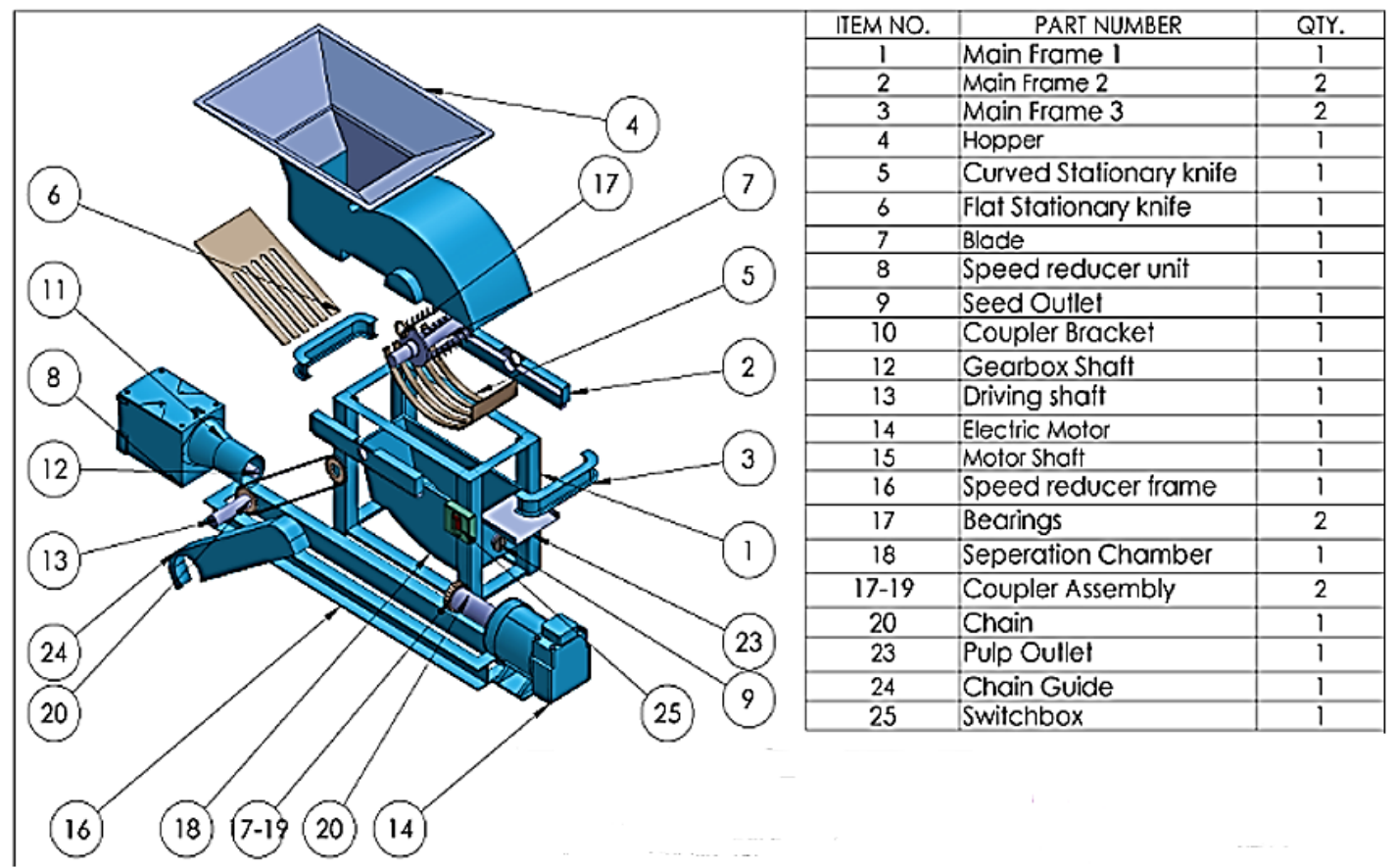

Figure 7. Exploded view of labeled parts of the machine

define the size and configuration of the geometry. Relations in the tool bar were used to define features such as parallelism, tangency, concentricity, perpendicularity among others. In the part assembly, sketches of individual parts were assembled together to form the intended solid model of the machine. Views were automatically generated from the solid model; and dimensions and tolerances were added to the drawing as required. SOLIDWORKS software have been successfully employed in modelling of reciprocating piston [21], remotely controlled hydraulic Bottle Jack [22], vehicle compression springs [23], two stroke internal combustion engine [24], High Density Polyethylene Liner HDPL [25], weld bead penetration on AISI 1020 low carbon steel plate [26] etc. Design drawings of the melon depodding machine were carried out to determine the specific dimension to be selected for each of the machine components. Figure 1-5 represents the isometric and orthographic views with dimensions of the major components constituting the melon depodding machine. Figure 6 shows isometric views of the melon deponding machine assembly while Figure 7 shows the exploded view of labeled parts of the machine.

Design calculations were carried out to determine the parametric range suitable for optimum operation of the machine. The volume of the truncated pyramid hopper in Figure 8 was calculated using Equation 1.

$$
V_{h}=\frac{1}{3}\left(a^{2}+a b+b^{2}\right) h=0.1157 m^{3}
$$

In other to determine the cutting force of the machine, the pressure relation was used. This is given by Equation 2 .

$$
P=\rho g h
$$

where, $\mathrm{p}$ is the density of stainless steel blade material (7850 $\mathrm{kg} /$ ), g is the acceleration due to gravity and $\mathrm{h}$ is the distance. With the swept volume of the stainless steel blade given as
$0.000127 \mathrm{~m}^{3}$, the mass of the blade can be obtained using the density relationship in Equation 3b.

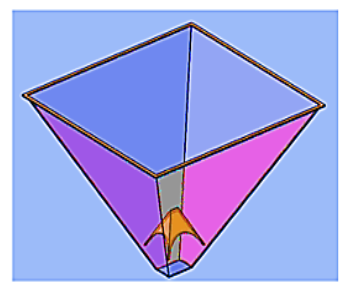

$\mathrm{a}=580 \mathrm{~mm}=0.58 \mathrm{~m}$

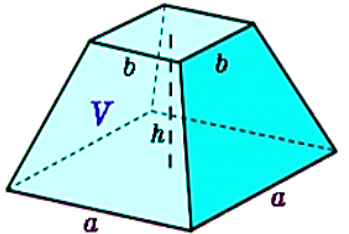

$\mathrm{b}=310 \mathrm{~mm}=0.31 \mathrm{~m}$

$\mathrm{h}=420 \mathrm{~mm}=0.42 \mathrm{~m}$

Figure 8. A truncated pyramid hopper with the dimensions4

$$
\begin{aligned}
& \rho=\frac{m}{v} \\
& m=\rho v \\
& m=7850 \times 0.000127=0.997 \mathrm{~kg}
\end{aligned}
$$

We know that torque is the turning force of the blades. This is determined by Equation 4.

$$
\text { Torque }(\mathrm{T})=\text { Force }(\mathrm{F}){ }^{*} \text { Radius }(\mathrm{r})
$$

Substituting values into Equation 4,

$$
\mathrm{T}=222.2 \times 0.07=15.55 \mathrm{~N}-\mathrm{m}
$$

To design for the power required to operate the machine, Equation 5 can be employed [27].

$$
\text { Power, }(\mathrm{P})=\text { Force }(\mathrm{F}) \times \text { Velocity }(\mathrm{V})
$$

Recall that,

$$
\mathrm{v}=\frac{2 \pi N}{60}
$$


where $\mathrm{N}$ is the rotational speed of the driver sprocket

Substitute Equation (5) into Equation (6),

$$
\begin{aligned}
& P=\frac{2 \pi N F}{60} \\
& P=\frac{2 \times 3.142 \times 48 \times 222.2}{60}=1117 \text { watts }
\end{aligned}
$$

But; 746watts $=1$ horse power $(1 \mathrm{hp})$

This implies that; 1117 watts $=1.5 \mathrm{hp}$

Taking a service factor of 1.5

$1.5 * 1.5 \mathrm{hp}=2.25 \mathrm{hp}$

Therefore, $2.5 \mathrm{hp}$ electric motor is required.

To design for the speed reducer unit, Equation 8 was employed [28].

$$
\frac{D_{1}}{D_{2}}=\frac{N_{2}}{N_{1}}
$$

were Electric motor speed $\left(\mathrm{N}_{1}\right)$ is $1440 \mathrm{rpm}$, driver sprocket diameter $\left(D_{1}\right)$ is $100 \mathrm{~mm}$, driven sprocket diameter $\left(D_{2}\right)$ is $50 \mathrm{~mm}$ and $\mathrm{N}_{2}$ is the rotational speed of the driver sprocket unknown.

$$
\begin{aligned}
& N_{2}=\frac{N_{1} \times D_{1}}{D_{2}} \\
& N_{2}=\frac{1440 \times 100}{50}=2880 \mathrm{rpm}
\end{aligned}
$$

Using a speed reduction gear box of 60:1

$$
N_{2}=\frac{2880}{60}=48 \mathrm{rpm}
$$

The center to center distance between the driver and driven sprocket is given by Equation 10

$$
C=2 D_{1}+D_{2}
$$

where $D_{1}$ is the diameter of the driver sprocket $=100 \mathrm{~mm}=$ $0.1 \mathrm{~m}, \mathrm{D}_{2}$ is the diameter of the driven sprocket $=50 \mathrm{~mm}=$ $0.05 \mathrm{~m}, \mathrm{C}$ is the center distance between driver and driven sprocket. Therefore:

$$
C=2 \times(0.1+0.05)=0.3 m
$$

For a shaft subjected to combined bending and torsion, the equivalent twisting moment is given by Equation 11 while the equivalent bending moment is given by Equation 12 .

$$
\begin{aligned}
& T_{e}=\sqrt{\left(K_{m} \times M\right)^{2}+\left(K_{t} \times T\right)^{2}} \\
& M_{e}=\frac{1}{2}\left[K_{m} \times M+\sqrt{\left(K_{m} \times M\right)^{2}+\left(K_{t} \times T\right)^{2}}\right]
\end{aligned}
$$

where $T_{e}$ is the equivalent twisting moment, $M_{e}$ is the equivalent bending moment, $\mathrm{K}_{\mathrm{m}}$ is the combined shock and fatigue factor for bending, $\mathrm{K}_{\mathrm{t}}$ is the combined shock and fatigue factor for torsion, $\mathrm{T}$ is the torque transmitted by the shaft, $\mathrm{M}$ is the bending moment. Recall that,

$$
\begin{aligned}
& \mathrm{T}=\mathrm{F} \times \mathrm{r}=222.2 \times 0.07 \\
& \mathrm{~T}=15.55 \mathrm{~N}-\mathrm{m}
\end{aligned}
$$

Maximum bending moment of a simply supported shaft carrying a central load is given by Equation 13,

$$
\begin{aligned}
& M=\frac{W \times l}{4}=\frac{222.2 \times 0.31}{4}=17.22 \mathrm{Nm} \\
& \therefore T_{e}=\sqrt{\left(K_{m} \times M\right)^{2}+\left(K_{t} \times T\right)^{2}} \\
& T_{e}=\sqrt{(3 \times 17.22)^{2}+(3 \times 15.55)^{2}}=69.6 \mathrm{Nm}
\end{aligned}
$$

But;

$$
T_{e}=\frac{\pi \tau d^{3}}{16}
$$

Where the allowable shear stress $(42 \mathrm{MPa})$ and $\mathrm{d}$ is is the shaft diameter

$$
\begin{aligned}
& \therefore d=\sqrt[3]{\frac{69.6 \times 16}{3.142 \times 42 \times 10^{6}}} \\
& d=0.02 \mathrm{~m} \text { or } d=20 \mathrm{~mm}
\end{aligned}
$$

Using a service factor of 1.75

$$
\begin{aligned}
& d=20 \times 1.75 \\
& d=35.63 \mathrm{~mm} \text { say } 35 \mathrm{~mm}
\end{aligned}
$$

We know that the equivalent bending moment,

$$
\begin{aligned}
& M_{e}=\frac{1}{2}\left[K_{m} \times M+\sqrt{\left(K_{m} \times M\right)^{2}+\left(K_{t} \times T\right)^{2}}\right] \\
& =\frac{1}{2}\left[3 \times 17.22+\sqrt{(3 \times 17.22)^{2}+(3 \times 15.55)^{2}}\right] \\
& =\frac{1}{2}(51.66+69.6)=60.63 \mathrm{Nm}
\end{aligned}
$$

But;

$$
M_{e}=\frac{\pi \sigma_{b} d^{3}}{32}
$$

where $\sigma_{b}$ is the maximum tensile or compressive stress (84 $\mathrm{MPa}$ ) and $\mathrm{d}$ is the shaft diameter.

$$
\begin{aligned}
& \therefore d=\sqrt[3]{\frac{32 \times 60.63}{3.142 \times 84 \times 10^{6}}}=\sqrt[3]{7.35 \times 10^{-6}} \\
& d=0.0194 \mathrm{~m} \text { or } d=19.4 \mathrm{~mm}
\end{aligned}
$$

Using a service factor of 1.75

$$
\begin{aligned}
& d=19.4 \times 1.75 \\
& d=33.95 \text { say } 35 \mathrm{~mm}
\end{aligned}
$$

Figure 9 represents an isometric view of the depodding mechanism with bearings mounted on it while Figure 10 shows the bearing configuration diagram with the bearings positioned at point $\mathrm{A}$ and $\mathrm{B}$.

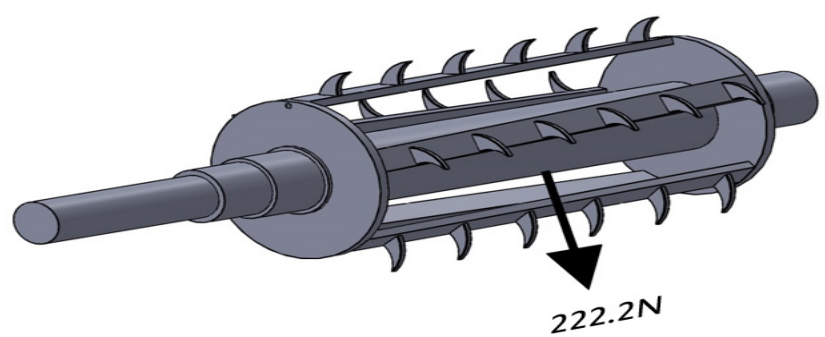

Figure 9. Pictorial view of the depodding mechanism

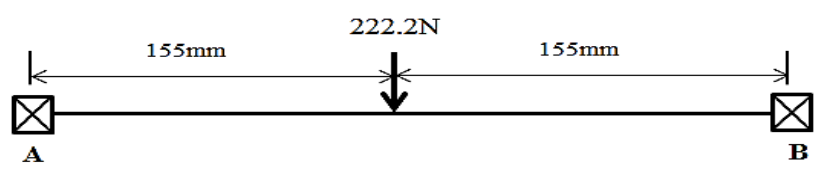

Figure 10. Bearing configuration diagram

$$
R_{A}+R_{B}=F
$$

Upward reaction (forces) = Downward reaction (forces)

This implies that:

$$
R_{A}+R_{B}=222.2 N
$$

Taking moment about point $\mathrm{A}$; 
$222.2(155 m m)-R_{B}(310 m m)=0$

Sum of clockwise moment is equal to sum of anti-clockwise moment

$222.2 \mathrm{~N} \times 155 \mathrm{~mm}=R_{B} \times 310 \mathrm{~mm}$

Therefore;

$$
R_{B}=\frac{222.2 \times 155 \mathrm{~mm}}{310 \mathrm{~mm}}=111.1 \mathrm{~N}
$$

But;

$$
R_{A}+R_{B}=222.2 N
$$

Therefore;

$$
R_{A}=222.2 \mathrm{~N}-111.1 \mathrm{~N}=111.1 \mathrm{~N}
$$

Determination of the loading factors on bearing A can be expressed as follows:

$$
L_{10}=\frac{60 \times L \times N}{10^{6}}
$$

where $\mathrm{L}_{10}$ is the basic dynamic life of the bearing, $\mathrm{L}$ is the life of the bearing

$$
\begin{aligned}
L & =18,000 \leq 22,000 \\
\mathrm{~N} & =1440 \mathrm{rpm}
\end{aligned}
$$

Therefore;

$$
L_{10}=\frac{60 \times 22,000 \times 1440}{10^{6}}=1900.8 \text { millions of revolution }
$$

Also;

$$
F_{e}=\left(X C_{r} F_{r}+C_{t} F_{t}\right) S_{f}
$$

where $\mathrm{F}_{\mathrm{e}}$ is equivalent dynamic load, $\mathrm{x}$ is the rotational factor, $\mathrm{C}_{\mathrm{r}}$ is the radial factor, $\mathrm{F}_{\mathrm{r}}$ is the radial load, $\mathrm{C}_{\mathrm{t}}$ is the thrust factor, $F_{t}$ is the thrust load, $S_{\mathrm{f}}$ is the safety factor, $\mathrm{x}=$ 1 (inner raceway), $\mathrm{F}_{\mathrm{t}}=0$ (bearing not carrying axial load). Equation 18 reduces to:

$$
\begin{aligned}
& F_{e}=\left(X C_{r} F_{r}\right) S_{f} \\
& S_{f}=1.1 \leq S_{f} \leq 1.5
\end{aligned}
$$

\section{Equation 21 is applicable to rotating parts}

$$
\frac{f_{t}}{X F_{r}} \leq Q
$$

$\mathrm{C}_{\mathrm{r}}=1$ and $\mathrm{C}_{\mathrm{t}}=0$

However if;

$$
\begin{aligned}
& \frac{f_{t}}{X F_{r}}>Q \\
& \mathrm{C}_{\mathrm{r}}=0.56
\end{aligned}
$$

where $Q$ is the determining factor, $C_{t}$ is either is interpolated or extrapolated for

But;

$$
\frac{0}{1 \times 138.91 N}=0 \leq Q
$$

Therefore,

$\mathrm{C}_{\mathrm{r}}=1$ and $\mathrm{C}_{\mathrm{t}}=0$

Hence;

$$
F_{e}=(1 \times 1 \times 111.1 N)=111.1 N
$$

The basic dynamic load can be calculated from the equation;

$$
C=L_{10}^{1 / k} \cdot F_{e}
$$

where $\mathrm{C}$ is the basic dynamic load, $\mathrm{K}$ is equal to 3 (Ball bearing)

Therefore,

$$
C=\sqrt[3]{1900.8} \times 111.1 N=1376.24 N
$$

Determination of the loading factors on bearing $\mathrm{B}$ can be expressed as follows:

$$
L_{10}=\frac{60 \times 22,000 \times 1440}{10^{6}}=1900.8 \text { millions of revolution }
$$

Also;

$$
\begin{aligned}
& F_{e}=(1 \times 1 \times 111.1 N)=111.1 N \\
& C=\sqrt[3]{1900.8} \times 111.1 N=1376.24 N
\end{aligned}
$$

Average dimension of a melon pod from experiment was obtained from Equation 24, while average diameter of a melon pod was obtained from Equation 25.

$$
\begin{aligned}
& \text { Average Mass of Melon Pod, } M_{\text {avg }}=\frac{\text { Total Mass of Pod }}{\text { Total Number of Pod }} \\
& \text { Average Diameter of Pod, } D_{\text {avg }}=\frac{\text { Total Diameter of Pod }}{\text { Total Number of Pod }}
\end{aligned}
$$

In order to calculate the performance efficiency of depodding melon, it was necessary to determine the ratio or the percentage of extractable seeds per given mass of melon pods. The percentage seed depodded was calculated using Equation 26, percentage of undepodded seeds was calculated using Equation 27 while the percentage of damaged seeds was determined using Equation 28.

$$
\begin{aligned}
& \text { percentage seed depodded }=\frac{\text { Number of depodded seeds }}{\text { Total number of seeds }} * \frac{100}{1} \\
& \text { percentage seed undepodded }=\frac{\text { Number of undepodded seeds }}{\text { Total number of seeds }} * \frac{100}{1} \\
& \text { percentage of damaged seeds }=\frac{\text { Number of damaged seeds }}{\text { Total number of seeds }} * \frac{100}{1}
\end{aligned}
$$

The useful seeds are both the depodded seeds and undepodded seeds, this accounts for the total number of seeds that are still usable i.e., it is the sum of the depodded seeds and the undepodded seeds. Though the undepodded seeds does not add to the efficiency of the machine but these seeds are still very much usable so long they can be recovered. This is calculated using Equation 29.

percentage of useful Seeds $=100$ - percentage of damage seeds

Materials employed in the fabrication process of the melon decoding machine which came with different sizes, dimensions and geometries were purchased from the open market. The fabrication process of the machine involved cutting of the materials into specific sizes and joining them together through welding method. The procedures are highlighted as follows:

- Measurement: The materials used in the fabrication process of the machine were measured to required dimensions using measuring tape and Vernier caliper.

- Marking Out: After measuring the required dimension, 


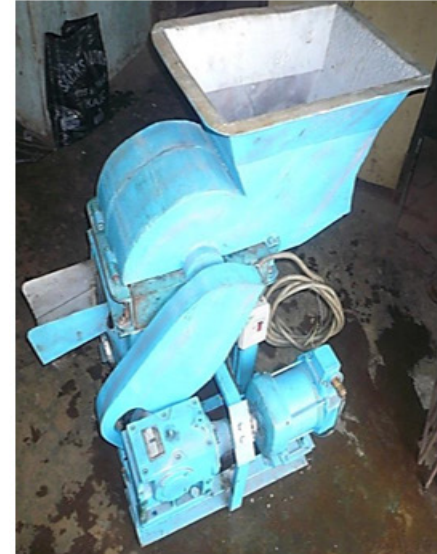

a

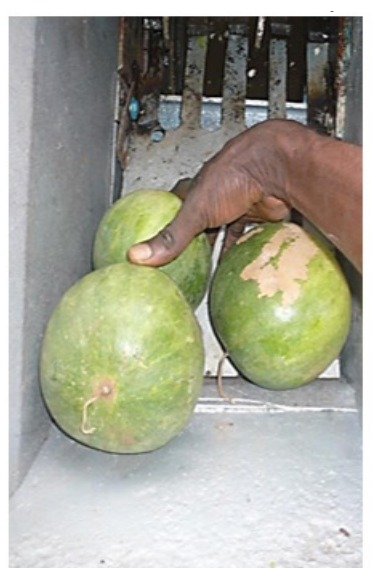

b

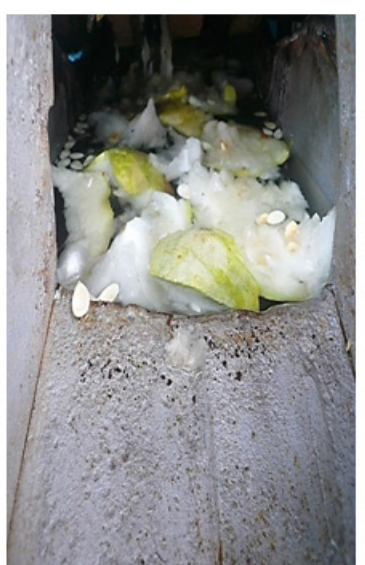

c

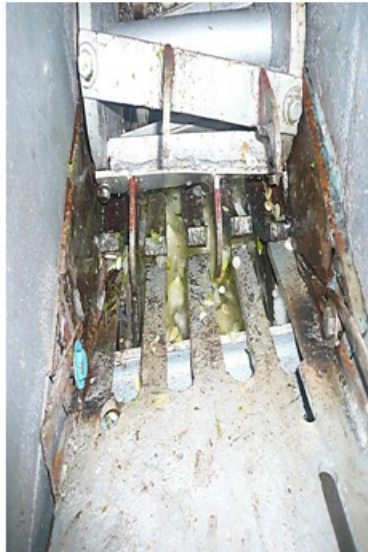

d

Figure 11. Pictorial views of fabricated machine and testing process

white chalk was used to mark out a line on the material to indicate the areas that are meant to be cut.

- Cutting: The marked out parts were cut according to the dimensions specified on the working drawings in Figure 1-5. Handheld cutting machine and sawing equipment was used to carry out the cutting operation.

- Drilling and Boring Operation: Drilling and boring operations are mainly used in making holes for temporary joints. On the other hand, boring is simply enlarging the drilled hole to the required dimension. Both operations were applied in fabrication of the machine especially in the parts/components where bolt and nuts were required during installation.

- Welding: Welding involves the joining of two or more metals together and this can be achieved either by gas welding or arc welding which is the most common welding operation. After cutting the various materials to required shapes and sizes, welding was used to join together.

- Grinding and Filling operation: These methods were used to smoothen the surface of the welded and rough areas on the body of the depodding machine as well as removing unwanted parts and metals to achieve good surface finish.

- Finishing: After the welding operation, rough edges and entire body surface of the machine was smoothened using emery paper, afterwards, the machine was painted to prevent the surface from corrosion.

The melon depodding machine is composed of a set of blades arranged in pairs and attached to a circular plate, with a rotating shaft passing through the center of the circular plate in the melon depodding chamber. The melon pods are fed into the machine through the truncated pyramid hopper where they contact with the blades in the depodding chamber and are crushed. The crushed melon pieces are released into the separation chamber containing water, where the seeds are separated from the pulp. The whole unit is powered by an electric motor of $2.5 \mathrm{hp}$ with a speed of $1440 \mathrm{rpm}$. In other to increase the torque, a speed reducer unit was attached to the electric motor to obtain the desired speed of $30 \mathrm{rpm}$. The speed reducer unit does the function of reducing the speed and avoiding the anticlockwise rotation of the electric motor while increasing the torque of the system. The electric motor was connected to the speed reducer unit through a chain and sprocket connection. Power is then transmitted to the depodding chamber through sprocket and chain drive. The depodding chamber had a configuration of stainless steel blade placed on a flat bar with alternate distance to each other. The design is composed of a set of the blade (two per bar) mounted on a rotating circular plate. The working mechanism is that of a hammer mill. The rotating blade cuts the melon pod against a stationary knife, the cut particles are released into the separation chamber containing water. The pulp floats while the seeds settle at the bottom of the separation pan.

\section{RESULTS AND DISCUSSION}

The results obtained from the design calculation of the melon depodding machine are tabulated in Table 3.

Table 3. Results of parameters calculated in this study

\begin{tabular}{|c|c|c|}
\hline $\mathrm{S} / \mathrm{N}$. & Parameters & Calculated Values \\
\hline 1. & volume of the hopper & $0.1157 \mathrm{~m}^{3}$ \\
\hline 2. & Mass of stainless steel blade & $0.997 \mathrm{~kg}$ \\
\hline 3. & Torque $(T)$ transmitted by the shaft & $15.55 \mathrm{~N}-\mathrm{m}$ \\
\hline 4. & Power from electric motor & $2.5 \mathrm{hp}$ \\
\hline 5. & $\mathrm{~N} 1$ is the electric motor speed & $1440 \mathrm{rpm}$ \\
\hline 6. & $\mathrm{~N} 2$ is the rotational speed of the driver sprocket & $2880 \mathrm{rpm}$ \\
\hline 7. & Using a speed reduction gear box of $60: 1 \mathrm{~N}_{2}$ is & $48 \mathrm{rpm}$ \\
\hline 8. & Centre distance between driver and driven sprocket & $0.3 \mathrm{~m}$ \\
\hline 9. & Driven sprocket diameter $\mathrm{D}_{2}$ & $50 \mathrm{~mm}$ \\
\hline 10. & Driver sprocket diameter $\mathrm{D}_{2}$ & $100 \mathrm{~mm}$ \\
\hline 11. & Maximum bending moment $(M)$ on shaft & $17.22 \mathrm{Nm}$ \\
\hline 12. & Equivalent twisting moment $\left(T_{e}\right)$ on shaft & $69.6 \mathrm{Nm}$ \\
\hline 13. & Allowable shear stress $\tau$ & $42 \mathrm{MPa}$ \\
\hline 14. & Shaft diameter & $35 \mathrm{~mm}$ \\
\hline 15. & Equivalent bending moment $(\mathrm{Me})$ on shaft & $60.63 \mathrm{Nm}$ \\
\hline 16. & Maximum tensile or compressive stress $\left(\sigma_{b}\right)$ & $84 \mathrm{MPa}$ \\
\hline 17. & Basic dynamic life of the bearing $\left(\mathrm{L}_{10}\right)$ & $\begin{array}{c}1900.8 \text { millions of } \\
\text { revolution }\end{array}$ \\
\hline 18. & Equivalent dynamic load on the bearing $\left(\mathrm{F}_{\mathrm{e}}\right)$ & $111.1 \mathrm{~N}$ \\
\hline 19. & Basic dynamic load on the bearing (C) & $1376.24 \mathrm{~N}$ \\
\hline
\end{tabular}


Determination of the average diameter and mass of the melon pod is very crucial in the development of the melon depodding machine. A total of twenty (20) melon pods were collected from the study area, measured using vernier caliper and weighing balance, and readings were recorded and presented in Table 4 . The average mass of the pod was calculated to be $1.671 \mathrm{~kg}$ and the average diameter as $139.25 \mathrm{~mm}$. The result indicates that the mass and diameter of the melon pod are directly proportional to each other, which implies that, as the mass of the melon pod increase, the diameter of the melon pod also increases.

Table 4. Experimental results obtained for mass and diameter of melon pod

\begin{tabular}{|c|c|c|}
\hline $\mathrm{S} / \mathrm{N}$ & Diameter of Melon Pod $(\mathrm{mm})$ & Mass of Melon Pod $(\mathrm{kg})$ \\
\hline 1 & 138 & 1.50 \\
\hline 2 & 130 & 1.35 \\
\hline 3 & 158 & 2.20 \\
\hline 4 & 100 & 1.00 \\
\hline 5 & 110 & 1.10 \\
\hline 6 & 150 & 1.98 \\
\hline 7 & 158 & 2.00 \\
\hline 8 & 140 & 1.75 \\
\hline 9 & 135 & 1.50 \\
\hline 10 & 155 & 2.00 \\
\hline 11 & 138 & 1.51 \\
\hline 12 & 137 & 1.50 \\
\hline 13 & 160 & 2.50 \\
\hline 14 & 149 & 2.00 \\
\hline 15 & 153 & 1.70 \\
\hline 16 & 151 & 2.00 \\
\hline 17 & 134 & 1.53 \\
\hline 18 & 125 & 1.40 \\
\hline 19 & 115 & 1.10 \\
\hline 20 & 149 & 1.80 \\
\hline Average & 139.25 & 1.671 \\
\hline & & \\
\hline
\end{tabular}

Equation 24-28 was employed in the calculation of the mass of the melon pod, percentage of depodded seeds, percentage of undepodded seeds, percentage of damaged seeds, and the percentage of useful seeds. The results obtained from the calculation for 20 samples of fresh melon pods are tabulated in Table 5. From the averages calculated for each category of the result, it can be seen that for each sample of the fresh melon pod that is depodded using the machine, about 91\% of the depodded seeds are going to be obtained with over $1.5 \%$ damage.

\section{CONCLUSION}

A continuous melon depodding machine was successfully design and fabricated and this was aimed at solving an agelong manual depodding of the fresh melon pod. Test performance was carried out on the fabricated melon depodding machine to determine the average diameter and mass of a fresh melon pod as well as the percentage of depoded and undepodded seeds. The results obtained from the fabricated machine indicated that the problems associated with manual depodding of fresh melon pods have been overcome and that the machine can perform optimally for both domestic
Table 5. Result for the Percentage of depodded, undepodded and damaged seeds

\begin{tabular}{|c|c|c|c|c|c|}
\hline $\mathrm{S} / \mathrm{N}$ & $\begin{array}{c}\text { Mass of } \\
\text { Pod }\end{array}$ & $\begin{array}{c}\text { Percentage } \\
\text { of depodded } \\
\text { seeds (\%) }\end{array}$ & $\begin{array}{c}\text { Percentage of } \\
\text { undepodded } \\
\text { seeds }(\%)\end{array}$ & $\begin{array}{c}\text { Percentage of } \\
\text { damaged seeds } \\
(\%)\end{array}$ & $\begin{array}{c}\text { Percentage of } \\
\text { useful seeds } \\
(\%)\end{array}$ \\
\hline 1 & 1.50 & 90.12 & 8.72 & 1.16 & 98.84 \\
\hline 2 & 1.35 & 90.91 & 7.84 & 1.25 & 98.75 \\
\hline 3 & 2.20 & 90.91 & 7.44 & 1.65 & 98.35 \\
\hline 4 & 1.00 & 92.51 & 6.17 & 1.32 & 98.68 \\
\hline 5 & 1.10 & 92.05 & 6.69 & 1.26 & 98.74 \\
\hline 6 & 1.98 & 91.08 & 7.59 & 1.33 & 98.67 \\
\hline 7 & 2.00 & 89.61 & 8.6 & 1.79 & 98.21 \\
\hline 8 & 1.75 & 91.79 & 6.52 & 1.69 & 98.31 \\
\hline 9 & 1.50 & 90.31 & 8.55 & 1.14 & 98.86 \\
\hline 10 & 2.00 & 91.4 & 6.99 & 1.61 & 98.39 \\
\hline 11 & 1.50 & 92.22 & 6.34 & 1.44 & 98.56 \\
\hline 12 & 2.50 & 89.76 & 7.87 & 2.36 & 97.64 \\
\hline 13 & 2.00 & 90.41 & 7.75 & 1.85 & 98.15 \\
\hline 14 & 1.70 & 89.97 & 7.71 & 2.31 & 97.69 \\
\hline 15 & 2.00 & 90.24 & 7.78 & 1.99 & 98.01 \\
\hline 16 & 1.53 & 90.41 & 7.95 & 1.64 & 98.36 \\
\hline 17 & 1.40 & 90.63 & 8.16 & 1.21 & 98.79 \\
\hline 18 & 1.10 & 92.94 & 5.95 & 1.12 & 98.88 \\
\hline 19 & 1.80 & 94.07 & 4.09 & 1.84 & 98.16 \\
\hline 20 & 1.51 & 91.17 & 7.12 & 1.71 & 98.29 \\
\hline Ave. & 1.671 & 91.1255 & 7.2915 & 1.5835 & 98.4165 \\
\hline
\end{tabular}

and commercial sectors in Nigeria. With the average percentage of useful seeds of $98.4165 \%$, the depodding machine developed in this study can greatly enhance the production of melon seeds, with $2.36 \%$ of the average seed damage. This can enhance the production process of melon seeds in medium and large scale for domestic and industrial purposes.

\section{REFERENCES}

[1] Ikpe, A. E., Orhorhoro, E. K., Erhinyodavwe, O. (2018). Design of a Multi-Purpose Crushing Machine for Processing of Food Grains in Nigeria. International Journal of Research Publications, 9(1): 1-9.

[2] Nwakire, J. N., Ugwuishiwu, B. O., Ohagwu, C. J. (2011). Design, Construction and Performance Analysis of a Maize Thresher for Rural Dweller. Nigerian Journal of Technology, 30(2): 49-51.

[3] Penuel, B. L., Khan, E. M. and Maitera, M. O. (2013). Properties of Proximate Composition and Elemental Analysis of Citrullus Vulgaris (Guna) Seed. Bulletine of Environment, Pharmacology and Life Sciences, 2(2): 39-46.

[4] Umar, K. J., Hassan, L. G. Usman, H. and Wasagu, R. S. U. (2013) Nutritional Composition of the Seeds of Wild Melon Colocynthis Ecirrhosus. Pakistan Journal of Biological Sciences, 16(11): 536-540.

[5] Enujuigha, V. N. and Ayodele, O. O. (2003). Evaluation of nutrients and some anti nutrients in lesser-known, underutilized oils seeds. International journal of food science and technology 38(5): 525528.

[6] National Research Council, Policy and Global Affairs, Development, Security and Cooperation (2006). Lost Crops of Africa: Volume II: Vegetables. National Academies Press, ISBN: 9780309103336.

[7] Chen, H., Baerdemaeker, J. D., Bellon, V. (1996). Finite Element Study of the Melon for Non-destructive Sensing of Firmness. Transactions of the American Society of Agricultural Engineers, 39(3): 1057-1065. 
[8] Akubuo, C. O., Odigboh, E. U. (1999). Egusi fruit coring machine. Journal of Agricultural Engineering Research, 74: 121-126.

[9] Oluwole, O. O., Adedeji, A. S. (2012). Effect of Moisture Content and Inner Drum Rotation Speed on the Shelling Performance of a Melon Sheller, Science and Technology, 2(2): 21-26.

[10] Datsugwai, M. S. S., Aisha, A. and Vincent, B. T. (2019). Microbial Quality and Sensory Characteristics of Instant Nigeria Egusisoups. Annals. Food Science and Technology, 20(3): 494-501.

[11] Shittu1 S. K., Ndrika, V. I. O. (2012). Development and performance tests of a melon (Egusi) seed shelling machine 1(2): 1-11.

[12] Jolaoso, A. A., Ajayi, J. O., Ogunmuyiwa, S. I. O. and Albert, O. M. (2014). Functional Proximate and Mineral Composition of a lesser known Fermented Legume (Fermented Seeds of Cathormion Altissimum, Oso). Journal of Emerging Trends in Engineering and Applied Sciences, 5(2): 129-134.

[13] Norton, G. (1993). Guna seed analysis. Applied Biochemistry and Food Science Department, University of Nottingham, UK.

[14] Oyediran, W. O. (2013). Factors affecting melon (Citrullus colocynthis) production in Oyo state, Nigeria. Unpublished M. Agric. Thesis, Department of Agricultural Extension and Rural Development, Federal University of Agriculture Abeokuta, 71-73.

[15] Kushwaha, H. L., Strivastava A. P., Singh H. (2006). Development and Performance Evaluation of an okra seed Extractor. Agricultural Engineering International, 7: 1-13.

[16] Aviara, N. A., Hague, M. A. (2002). Processing and Storage of Guava Crop. Agricultural Mechanization in Asia, Africa and Latin America, 33(1): 49-54.

[17] Jackson, B. A., Adamade, C. A., Azogu, I. I., Oni, K. C. (2013). Melon pod fermentation and its effects on physiochemical characteristics of melon seeds. Scientific Research and Essays, 8(17): 664-669.

[18] Oriaku, E. C., Agulanna, C. N., Nwannewuihe, H. U. (2013). Comparative Performance Analysis of Melon (Colocynthis Citrullus L.) De-Husking and Separation Machines by Principles of Impact and Attrition. International Journal of Multidisciplinary Sciences and Engineering, 4(7): 53-59.

[19] Nwakuba, N. R. (2016). Performance Testing of a Locally Developed Melon Depodding Machine. International Journal of Agriculture, Environment and Bioresearch, 1(1): 7-25.

[20] Oloko, S. A., Agbetoye, L. A. S. (2006). Development and Performance Evaluation of a Melon Depodding Machine. Agricultural Engineering International: the CIGR e-Journal, 8: 1-10.

[21] Ikpe A. E. And Owunna, I. B. (2020). Design Analysis of Reciprocating Piston for Single Cylinder Internal Combustion Engine. International Journal of Automotive Science and Technology, 4(2): 30-39.

[22] Ikpe A. E. And Owunna, I. B. (2019). Design of Remotely Controlled Hydraulic Bottle Jack for Automobile Applications. International Journal of Engineering Research and Development, 11(1): 124-134.

[23] Ikpe A. E. And Owunna, I. B. (2017). Design of Vehicle Compression Springs for Optimum Performance in their Service Condition. International Journal of Engineering Research in Africa, 33, 22-34.

[24] Ikpe A. E. And Owunna, I. B. (2020). A 3D Modelling of the In-Cylinder Combustion Dynamics of Two Stroke Internal Combustion Engine in its Service Condition. Nigerian Journal of Technology, 39(1), 161-172.

[25] Ikpe, A. E., Ndon, A. E and Adoh, A. U. (2019). Modelling and Simulation of High Density Polyethylene Liner Installation in Engineered Landfill for Optimum Performance. Journal of Applied Science and Environmental Management, 23(3): 449-456.
[26] Owunna, I., Ikpe, A. E. and Achebo, J. I. (2018). 3D Finite Element Modelling of Weld Bead Penetration in Tungsten Inert Gas (TIG) Welding of AISI 1020 Low Carbon Steel Plate, European Mechanical Science, 2(3): 96-105.

[27] Ikpe, A. E., Owunna, I. (2017). Design of Used PET Bottles Crushing Machine for Small Scale Industrial Applications. International Journal of Engineering Technologies, 3(3): 157-168.

[28] Ikpe, A. E., Owunna, I. (2019). Design of Automatic Cooling Power Hacksaw Machine for Multipurpose Applications. International Journal of Engineering Technology and Sciences, 6(1): 1-14. 